\title{
A Geological Framework of Alaska
}

\author{
by David B. Stone and Wesley K. Wallace
}

Much of Alaska is geologically complex and difficult to interpret because of the lack of continuity from one area to another. It was not until the recognition that large-scale motion of small fragments, or terranes, had occurred that it began to be possible to make any sense of the overall geology of Alaska. This led to the definition of tectonostratigraphic terranes and their recognition in many other parts of the world.

\section{Tectonostratigraphic Terranes}

The concept of tectonostratigraphic terranes (Jones et al., 1977, Howell et al., in Howell, 1985) grew from several different sources. In western Canada, Monger and Ross (1971) found that the fossil evidence required a major separation across what is now considered a terrane boundary. In southeast Alaska, Jones and others (1972) discovered that some rock suites had a greater similarity to suites much farther south than to their neighbours. Paleomagnetic data from the Alaska Peninsula (Packer and Stone, 1972) indicated a more southerly paleolatitude than would be expected if Alaska had remained fixed in position with respect to North America. These data, combined with the disparities in the rock record across many of the major faults of Alaska, led to the terrane concept.

Terranes are defined as "fault-bounded geologic entities of regional extent, each characterized by a geologic history distinct from that of neighbouring terranes" (Howell et al., 1985). This does not necessarily imply that a terrane is far-travelled, but simply that it is different from its neighbours. A complete map of the Alaskan terranes identified to date, which number in excess of 60 , is given by Jones et al. (1987) and Honger and Berg (1987). Figure $l$ is a simplified version.

\section{Alaska in its Global Setting}

An understanding of the global tectonic setting of northwestern North America is important because plate interactions similar to those seen today and operating since at least late Mesozoic time, have played an integral role in the amalgamation of Alaskan terranes. Alaska and parts of the Chukotka Peninsula of Siberia form the northwestern end of the North American plate (Fig. 2), though the Eurasia-North America boundary is poorly defined beyond the western end of the Aleutian island arc (Cook et al., 1986, Stone 1983).

The plate convergence due to the Arctic spreading center and the northwesterly moving Pacific plate has resulted in the Aleutian-Alaska Peninsula subduction zone. The Aleutian Islands form the western end of this zone where the north-dipping seismic zone and a well-defined line of volcanoes provide a classic example of a convergent plate boundary (Figs. 3 and 4 ). In contrast, the eastern end of the zone displays an anomalously wide section between the trench and the more steeply dipping part of the downgoing slab. This gently dipping plane of hypocenters can be traced for several hundred kilometres inland before it steepens significantly, as can be seen from the location of the $50 \mathrm{~km}$ hypocenter contour (Fig. 4).
Along the boundary between southeast Alaska and th Pacific plate, the trend of the principal strike-slip fault (th Fairweather) coincides very closely with the predicte. Pacific-North America motion, and represents a typica transform boundary. Between this and the equally well defined Aleutian-Alaska Peninsula subduction zone, there an area where relative plate interactions are complex an obscure (between the $R M-1$ lines in Fig. 4). An ill-define: Wadati-Beniof $f$ zone can be seen dipping steeply beneath th young volcanic rocks of the Wrangell Mountains (Stephens $e$ al., 1984). This seismie zone is considerably closer to th: Pacific than the well-defined, steeply-dipping zone to th: west and is oblique to the direction of Pacific plate convergence (Fig. 4).

One possible explanation is that the subduction zone is $i_{i:}$ the process of reorganizing and re-positioning itself. This is enhanced by evidence that the terrane forming the souther: margin of this part of Alaska, the Yakutat block (Fig. 1), is now in the process of accreting to Alaska, thus disrupting.

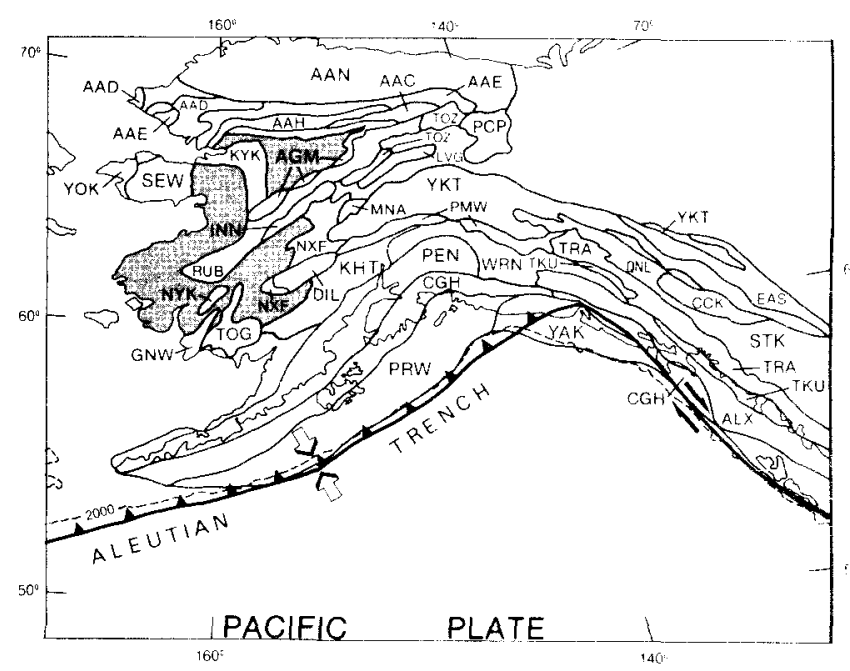

Figure 1: The major terranes of northwestern Nort America redrawn from Howell et ai., 1985. AAC-Arctil Alaska, AAD-Delong Mountains subterrane, AAE-Fndicott Mountains subterrane, AAli-Hammond subterrane, AAN-North slope subterrane, AGM-Angayucham, ALXAlexander, CCK-Cache Creek, CGH-Chugach, DIL-Di.llinger, EAS-Eastern composite (Kootenay, Sliae Mtr, McLeod, Cassiar, Monashee), GNW-Goodnews, INN-Innoko, KYK-Koyukuk, LVG-Livengood, MNA-Minchumina NXF-Nixon Fork, NYK-Nyack, PCP-Porcupine, PEN-Peninsular, PMW-Pingston, MCKinley and Windy combined, PRW-Prince William, QNL-Quesnelilia, RUB-Ruby, SEWSeward Peninsula, STK-Stikinia, TKU-Taku, TOG. Togiak, TOZ-Tozitna, TRA-Tracy Arm, WRN-Wrangellia; YAK-Yakutat, YKT-Yukon-Tanana, YOK-York. The shaded areas represent onlap sequences of mainly cretaceous age. 
the pre-existing subduction regime. Studies show that the Yakutat block is moving northward with respect to North America, in the same direction but at a slower rate than the Pacific plate (Lahr and Plafker, 1980).

In addition to the seismicity associated with the subduction and transform boundaries described above, interior and parts of Arctic Alaska also show significant but shallow seismicity, especially distributed in a NW-SE band across interior Alaska. The reason for this is obscure, but the general distribution of all seismic events can be explained in terms of terranes that are at least partially coupled to the Pacific plate acting as a rigid indentor impinging on Alaska. The only part of Alaska that has no record of significant seismicity is the Arctic slope and the western and central Brooks Range north of the continental divide (Estabrook et al., in press).

An important effect of long-term subduction of the Pacific plate is that any large fragments carried by it, such as oceanic plateaus, magmatic arcs and segments of continental margins, will be accreted to the Alaskan margin. In fact, the Pacific plate and its predecessors have had a significant component of northward motion with respect to Alaska for at least the last $115 \mathrm{Ma}$ (Engebretson et al., 1985).

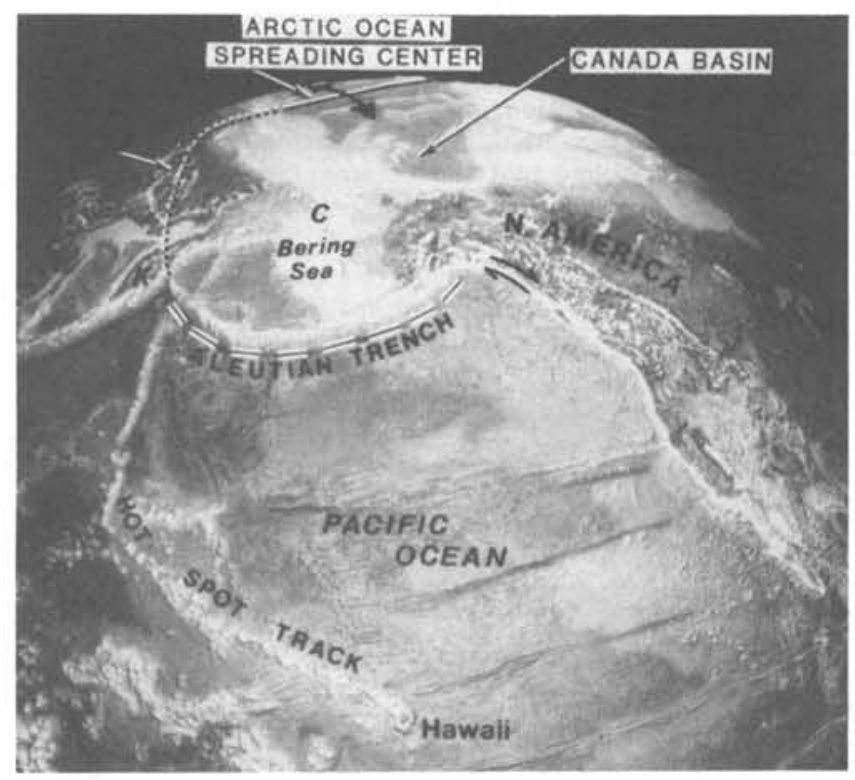

Figure 2: This global view shows Alaska's setting between the north Pacific and Arctic oceans. Dotted line is presumed boundary between North American and Eurasian plates. The hot spot track generated by the Hawaiian volcanoes indicates the motion of the Pacific plate in the past. C-Chukotka, K-Kamchatka.

In summary, the relative motions between the North American plate and the northward moving Pacific plate are being taken up along the Aleutian subduction zone, where the Pacific plate is being subducted. In south-central Alaska, the seismicity indicates large-scale underthrusting driven by the Pacific plate, and may imply a mechanism for sliding one slice or terrane under another. In southeast Alaska and the Yakutat area, because there is a change in the orientation of the plate boundary with respect to relative plate motion, there is a transition to a different mechanism. It appears that these terranes have moved along a transform plate margin, perhaps disrupting a previous subduction regime upon reaching the eastern Gulf of Alaska margin.
For the purpose of discussion, Alaska can be divided into broad areas or provinces grouping geological or tectonic styles that are similar (Fig. 5). However, because of the complexities of Alaskan geology these subdivisions can only be used as general guides.

\section{The Arctic Slope}

A broad province of low rolling hills and a wide coastal plain, the Arctic slope occurs between the mountains of the Brooks Range and an Atlantic-style continental margin to the north. Here Mesozoic and older rocks dip gently southward beneath an elongated basin parallel to the trend of the Brooks Range, the Colville trough. The northern flank of the basin is a structural sill parallel to the continental margin. The basin is filled with upper Mesozoic and Tertiary clastics, the distribution of which indicates that the basin was actively subsiding during deposition (see also Masters and Mast, this issue). The sediments eventually overfilled the basin to form a large sedimentary wedge across the continental margin. The direction of sediment transport, both in the Arctic slope and the Brooks Range, changed from generally southward during Paleozoic and early Mesozoic time to northward in late Mesozoic and Tertiary time. This change reflects the appearance of the Brooks Range as the major sediment source.

\section{The Brooks Range and Ruby Schist Belts}

The Brooks Range belt, which extends from the western edge of Alaska to the Richardson mountains in Canada, is dominated by east-west fold and thrust structures (e.g. Mull, 1982). It has been suggested (Mayfield et al., 1983) that the western end has undergone as much as $700 \mathrm{~km}$ of shortening, due to the stacking of at least seven major thrust sheets, beginning in Cretaceous time. Estimates of shortening at the eastern end are poorly constrained, and vary from very little to amounts comparable to those for the eastern end (e.g. Oldow et al., 1987).

The southern Brooks Range and Ruby schist belts are complex polymetamorphic assemblages, which have been overthrust by the Angayucham terrane, made up of rocks with oceanic affinities. The relationship between the schist belts is obscure. The overthrust Angayucham terrane is a stratigraphically complex assemblage of oceanic rocks, which range in age from Mississippian to Jurassic, and which may be an exposed extension of the Yukon-Koyukuk province.

\section{Yukon-Koyukuk and Related Units}

The Yukon-Koyukuk province forms a broad low-lying area, bounded on three sides by provinces characterized by extensive schist belts: the Seward Peninsula to the west, the Brooks Range schist belt to the north and the Ruby terrane to the southeast (Fig. 5). The basin extends southwest into the Yukon and Kuskokwim delta region. The Yukon-Koyukuk province includes rocks of an Early Cretaceous island arc, mid- to latest Cretaceous shelf and deep marine clastic deposits, and mid-Cretaceous to mid-Tertiary plutonic and voleanic rocks.

The origin of the basin is debatable, but one interpretation is that it is floored by a piece of ocean floor (the Angayucham terrane?) rafted into its present location. The collision of the island are built upon this ocean floor could have resulted in the formation of the Brooks Range. The YukonKoyukuk clastics are derived from and depositionally lap onto rocks of both the island arc and the terranes surrounding the basin, thus indicating geographic proximity of both by mid-Cretaceous time.

To the southwest, much of the bedrock in the Yukon and Kuskokwim river delta areas consists of Cretaceous sedimentary rocks co-extensive with, and indistinguishable from those of the Yukon-Koyukuk province, but the relationship between these sediments and the adjacent terranes is unclear. 


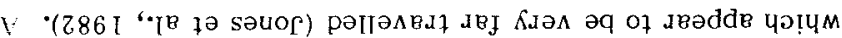

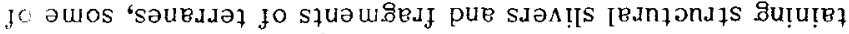

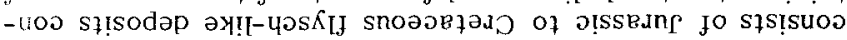

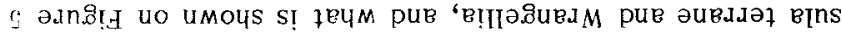

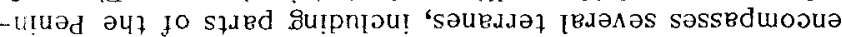

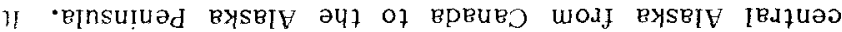
-

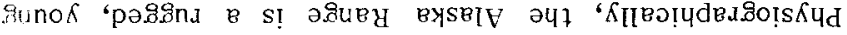

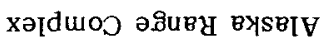

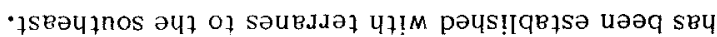

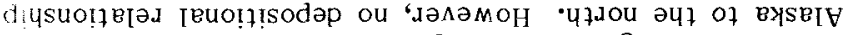
ac lapju! pue "

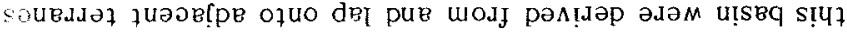
ii sł!sodap ग!

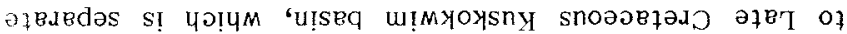

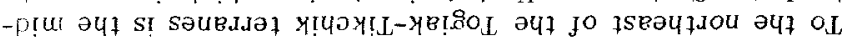

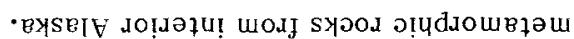

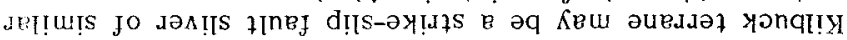

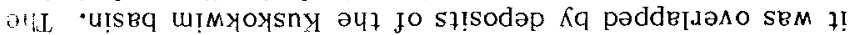

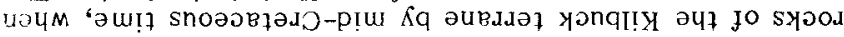

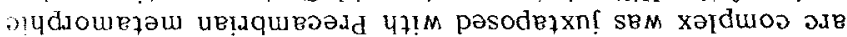

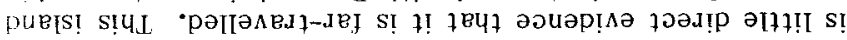

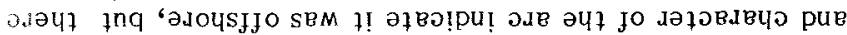

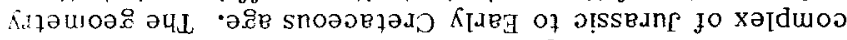

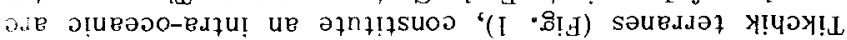

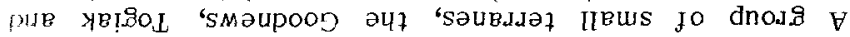

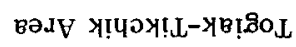

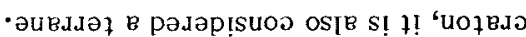

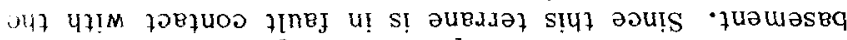
иəuqumbəadd $\mathrm{B}$ uo su!

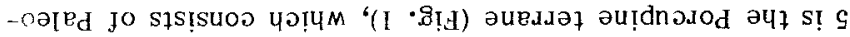

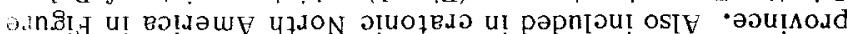

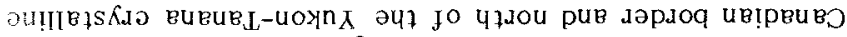

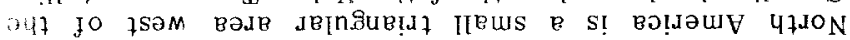

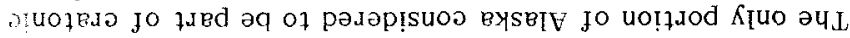

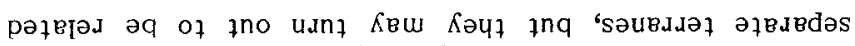

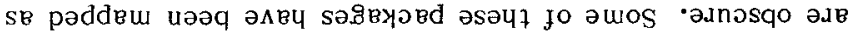

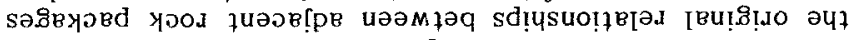

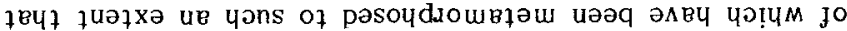

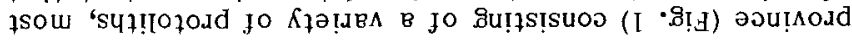

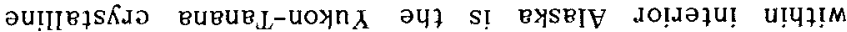

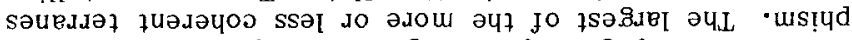

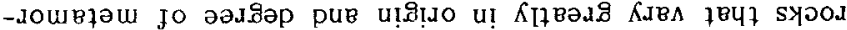

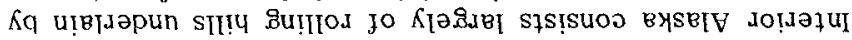

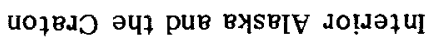

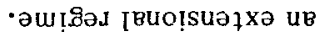

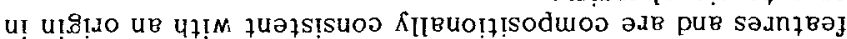

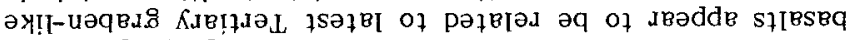

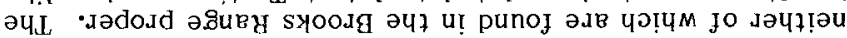

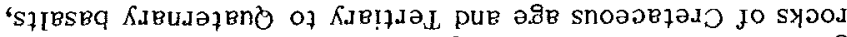

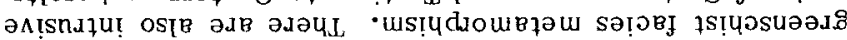

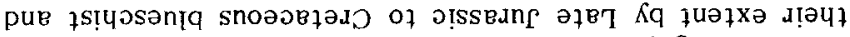

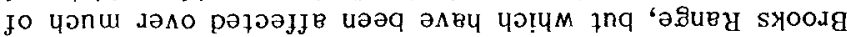

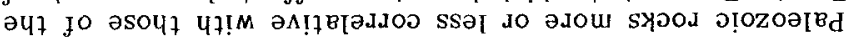

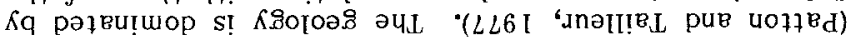
s!̣в

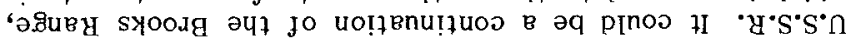

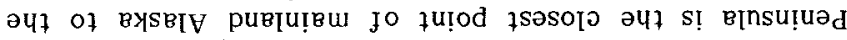

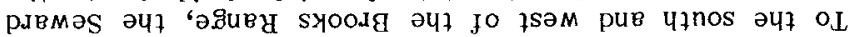

в[nsu!̣uad p.вməs

$\cdot u ! s 8 q$

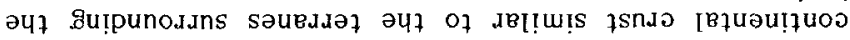

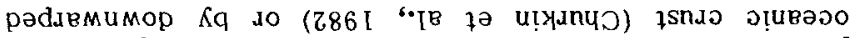
pəddejł $K \mathrm{q}$ u!̣

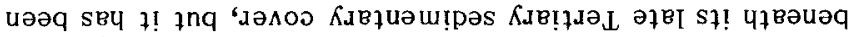

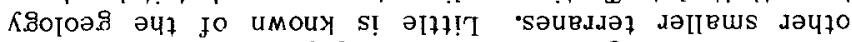
pue Buł!zoL "weyonkB.ిU

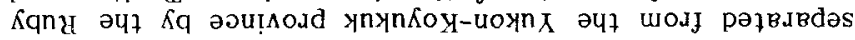

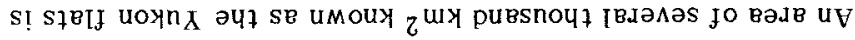

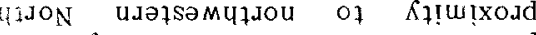
asolo кian!jejad u! sem bysetg jo jued

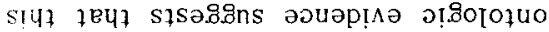

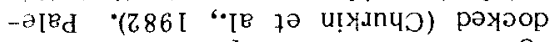

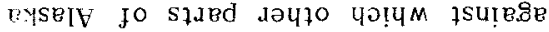
pus u!odew uвo!̣amy 4ł.10

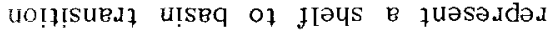
osayt s[apow auios uI solfselo pue

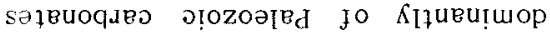

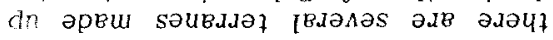

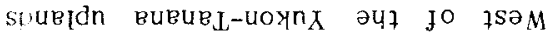

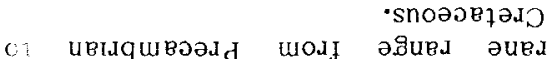
-d

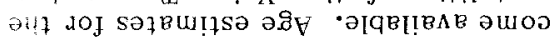

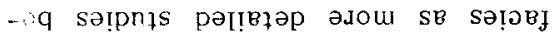

\footnotetext{
(・DL6L ' IE 72 Ja7suth paseq) azeTd otytoed aप7 xof

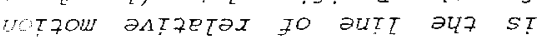

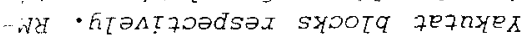

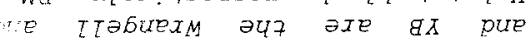

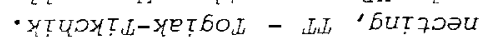
-Non-epuntps70L - DL 'euztsas -

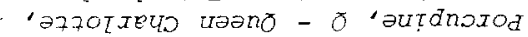
- 'euzeyoznh - $W$ 'ynqoX - LX AE7TEX - X 'YIOE UOXTN-OYOUUI -

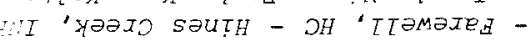
'xәyzezmxte. - A 'sayer outysq Ig w07ted - घG '746tej7s "Y7eUD - SO 'utezunow atases

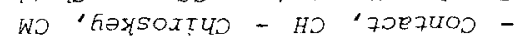
heg utnig - gg :s7ineg - azeId ftoed butzonpqns ouf pure exsetH s7TnEJ IOLEU כUL :E әInbT]
}

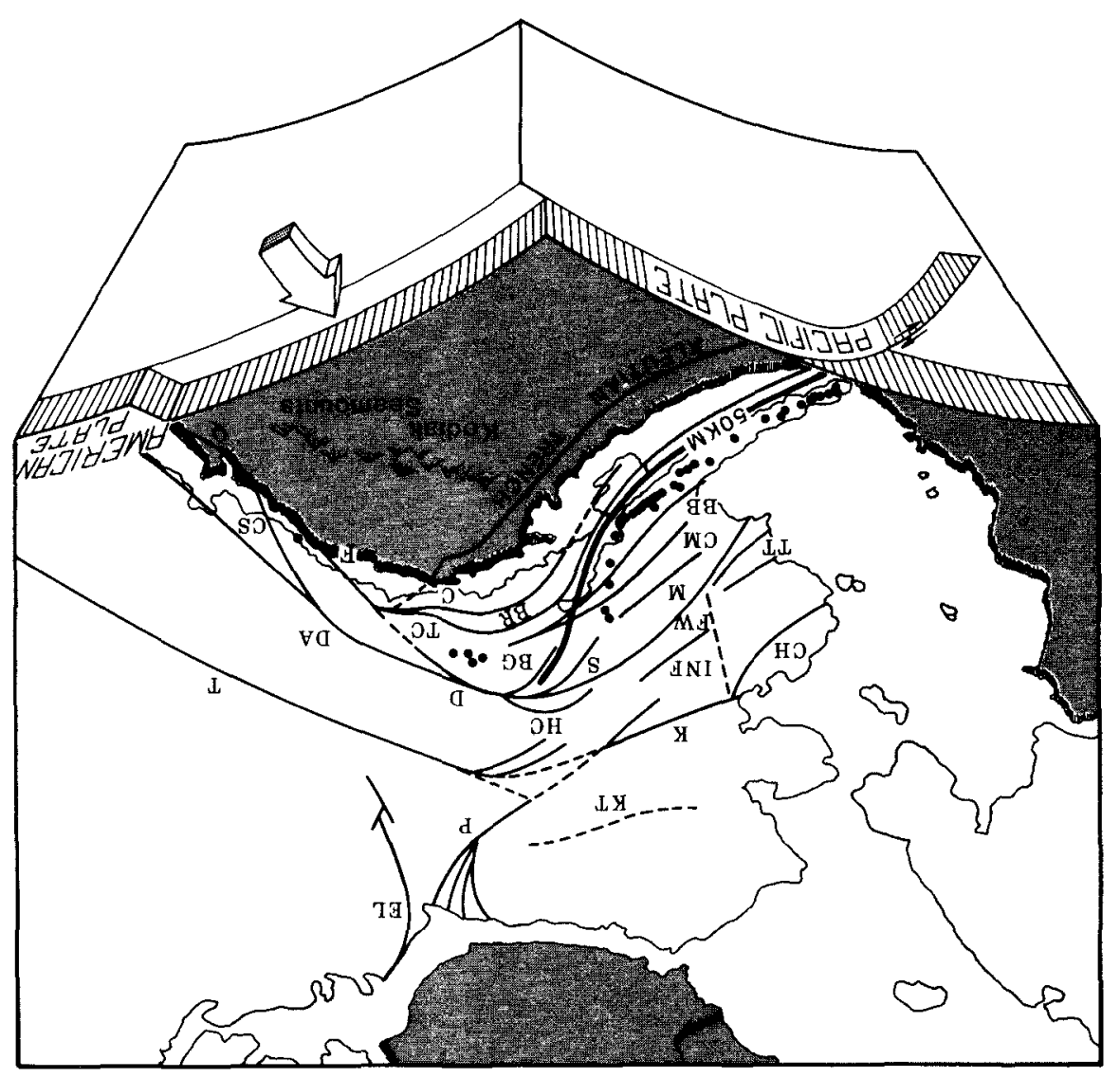




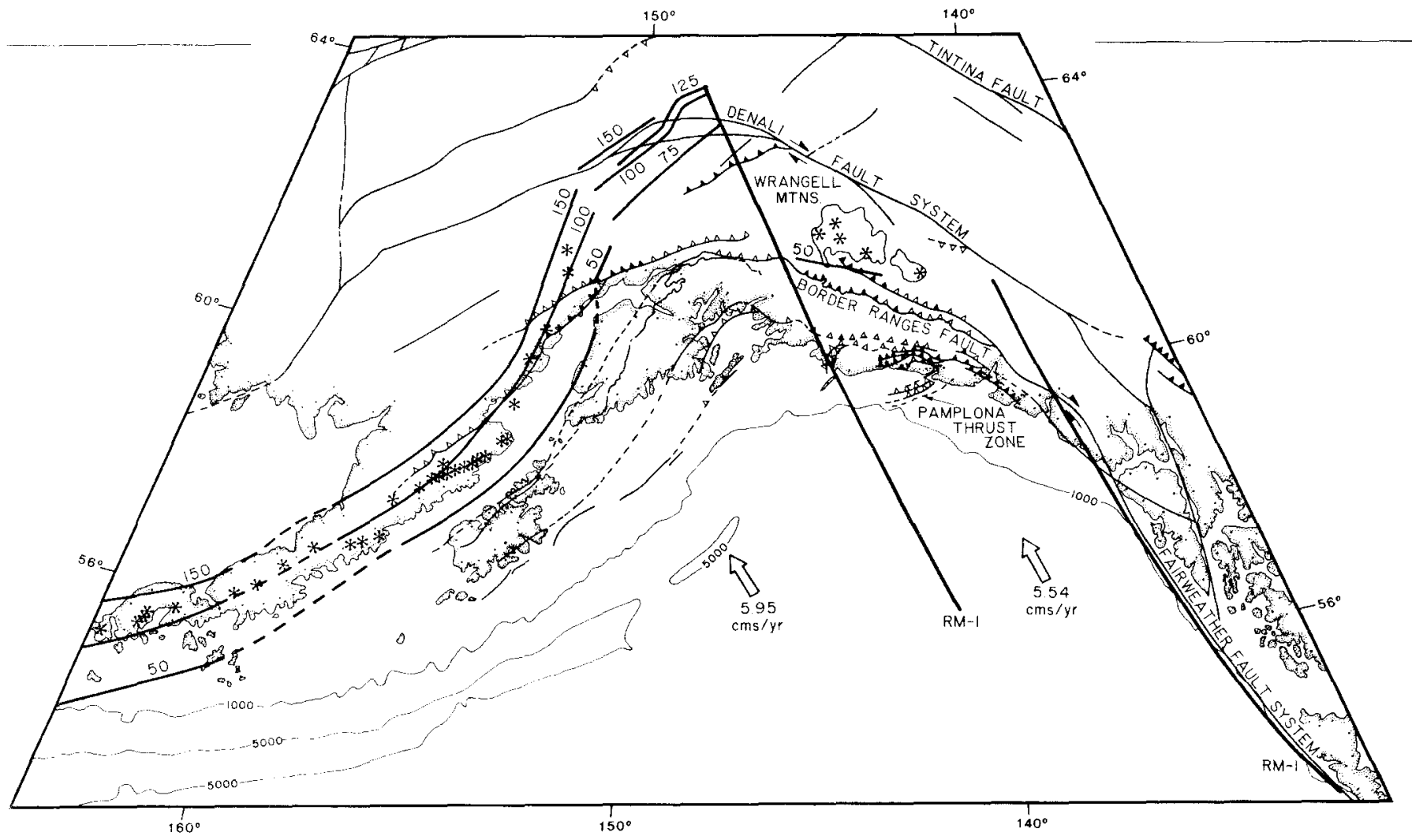

Figure 4: The Pacific-Alaska plate interaction in the Gulf of Alaska region (after Stone, 1983). Hypocenter depth contours (in $\mathrm{km}$ ) clearly define the lown-going slab. Stars - recent volcanoes. The RM-I Lines are the hypothetical tracks of the Pacific late about the Euler poles of Minster and others 1974).

key in the formulation of the terrane concept is the Chulitna (included in KHT in Fig. 1), which is only about 50 $\mathrm{km}$ in its longest dimension, but which includes Triassic redbeds that have no counterparts within a thousand miles or so (Jones et al., 1980). Cretaceous and younger plutonic rocks intrude the various older terranes of the region and constitute much of the extensive Alaska Range batholith as well as the tallest peak in North America, Mt. McKinley.

\section{Wrangellia}

I'he Wrangell Mountains lie between the eastern Chugach mountains and the Alaska Range. The Wrangell Mountains contain the "type locality" for Wrangellia, the first terrane to be defined as such (Jones et al., 1977). The distinctive sequence here of Triassic limestones and largely submarine low units suggests that Wrangellia may represent an ancient oceanic plateau. The appearance in mid- to late Iesozoic deposits of terrestrial detritus is indicative of its upproach to a continental margin and its eventual incorporation into North America.

The recognition of essentially identical sequences of rocks in other locations, particularly in southeast Alaska and British Columbia, led to the idea that the scattered sequences were all part of a much larger terrane that may have fragmented and dispersed after amalgamation with the continent. In south-central Alaska, Wrangellia underlies a large part of the Copper River basin and part of the south lank of the Alaska Range.

The Wrangell Mountains also contain a large volume of dominantly andesitic Tertiary rocks. The time of onset of the volcanism is uncertain, the oldest radiometric age determinations giving illocene ages. Volcanic activity has

continued up to the present, with Mount Wrangell having erupted in historic time. The relationship of these voleanic rocks to past and present subduction zones is unclear.

\section{The Alaska Peninsula Terrane}

The geological history of the Alaska Peninsula terrane is principally that of a magmatic arc and associated forearc deposits. This is dominated by a large composite batholith, together with sediments shed seaward from the magmatic arc and deposited in a nearshore environment. The batholith ranges in age, although not continuously, from Jurassic through mid-Tertiary. The older rocks of the region constitute the probably far-travelled Peninsula terrane (Fig. 1), which was joined to neighbouring Wrangellia by mid-Jurassic time. The Peninsula terrane was linked to more landward terranes by an extensive overprint of latest Cretaceous to Paleocene magmatism (Wallace and Engebretson, 1984).

The Alaska Peninsula is capped by the young volcanic rocks and active volcanoes of the modern magmatic arc, which is associated with the eastern part of the Aleutian-Alaska Peninsula subduction zone.

\section{Chugach Accretionary Complex}

Parallel to, and in places forming the rugged south coast of Alaska are the Chugach Mountains, dominated by flysch and mélange deposits of Cretaceous through late Tertiary age. They also include along their northern flanks some older sediments, plutonic rocks and ophiolite fragments interpreted as remnants of a Jurassic magmatic arc. The general interpretation of the Chugach Mountains is that they represent a succession of uplifted accretionary complexes, progressively younger from landward to seaward.

To the east, in the St Elias Range, uplift is still going on in response to the underthrusting of the Yakutat block. Several major faults traverse the length of the Chugach Mountains, including the Border Ranges and the Contact faults (Figs. 3 and 4). Both of these mark the location of major sutures between accreted packages, but the timing and sense of motion on these faults since their initial formation is unclear. 


\section{The Aleutian Island Arc}

The Aleutian island arc is the westward, intra-oceanic extension of the magmatic arc associated with subduction of the Pacific plate and consists of a chain of mainly volcanogenic islands. It is built upon a massive submarine ridge that stretches from the Alaska Peninsula westward to the Kamchatka Peninsula (Fig. 2), though the far western end is separated from Kamchatka by an oceanic deep. The age of formation of the arc is not well constrained, but it probably originated in Eocene time. The eastern two-thirds of the chain contains many active volcanoes, but at the western end, where the relative motion of the Pacific plate is more nearly parallel to the trend of the arc, there is no active volcanism today.

\section{Bering Sea Shelf}

The Bering Sea shelf is a very large continental shelf to the west of mainland Alaska. Occupying an area about twice the size of California, it is shallow and shows little topographic relief landward of its edges. Horizontal Tertiary deposits form the very flat sea floor covering older rocks about which little is known. Several very large canyons have developed at the shelf edge and are presumed to be structurally controlled erosional features.

Dredge samples from the edge of the continental shelf are similar to the Mesozoic clastic deposits of the Alaska Peninsula. Seismic and other geophysical data indicate that the rocks near the shelf edge have undergone considerable deformation. A series of deep, sediment-filled pull-apart basins of Tertiary age occur landward of and parallel to the Bering Sea shelf edge, including the Navarin basin that has a depth of about $15 \mathrm{~km}$, based on seismic studies.

\section{Southeast Alaska}

Southeast Alaska is physiographically a continuation of the rugged islands and coast ranges of Canada's British Columbia. The principal grain of the country trends north-south, parallel to the major strike-slip faults along this predominantly transform boundary. The geology is divided into terranes, in part bounded by these faults, and includes from seaward to landward: Cretaceous flysch deposits similar to those seen in the Chugach Mountains, parts of Wrangellia, the extensive Alexander terrane (Fig. 1) containing rocks spanning the Paleozoic, and the plutonic and metamorphic rocks of the late Mesozoic-Cenozoic Coast Mountains Batholithic complex. Inboard of these terranes, in British Columbia, are the Stikinia and Cache Creek terranes of late Paleozoic and Mesozoic age. The existence of older terranes outboard of younger ones is evidence for the complexities of terrane accretion and dispersion.

\section{The Tectonic Development of Alaska}

The first definitive paleomagnetic study following the reconnaissance studies of Packer and Stone (1972) showed that in Triassic time the newly defined terrane of Wrangellia was located at equatorial latitudes (Hillhouse, 1977). This led to the interpretation that Alaska is a complex collage of many different terranes that could be far-travelled. Later paleomagnetic data showed that many of the terranes of southern Alaska also originated far to the south of their present locations. It is yet to be fully resolved when and where the various terranes amalgamated and when they arrived in their present locations. The Yakutat block, as
Figure 5: A very generalized map of the major geological divisions of Alaska.

shown above, is still docking, but most of the rest of southern Alaska seems to have been in place at least by mid-Eocene time.

Different lines of evidence commonly indicate inconsistent times of arrival for the various terranes at their present locations. For example, paleomagnetic data from Wrangellia (Panuska, 1985) indicate that it was still significantly south of its present relative latitude in latest Cretaceous time. In contrast, the presence of plutonic belts extending across, and thus locking terrane boundaries indicate arrival by latest Cretaceous time. The travel histories of interior and Arctic Alaska are less well defined. The paleomagnetic data for interior Alaska indicate no significant latitudinal motion, but are sparse and are not definitive.

There are several models for the tectonic development of the Arctic Ocean basin and Arctic Alaska. These include clockwise rotation away from the Canadian Arctic islands, development in-place, and models that involve translation across the Arctic Ocean. The limited paleomagnetic data available for Arctic Alaska lead to mutually inconsistent conclusions. One data set, from borehole cores of Early Cretaceous age from the Arctic slope (Halgedahl and Jarrard, in press), is consistent with a rotation away from the Canadian Arctic islands. The other data, from Late Cretaceous sites both north and south of the Brooks Range, show Arctic Alaska, including the Yukon-Koyukuk province, to have been about $10-15^{\circ}$ farther south with respect to cratonic North America (e.g. Harris et al., 1987). In order for these two data sets to be compatible, Arctic Alaska must have rotated farther to the south in Early Cretaceous time than is required by the simple rotation model, then moved partway back by latest Cretaceous time, perhaps in response to collision of terranes from the south.

Throughout Alaska there is evidence of pervasive resetting of potassium-argon $\mathrm{K}$-Ar ages by events in mid-Cretaceous time. This is seen in the rocks of the accreted terranes of southwest Alaska, in many of the metamorphic terranes and throughout the southern Brooks Range. It is also seen in the 
large number of reset paleomagnetic directions throughout the Brooks Range and interior Alaska and to a lesser degree in the terranes of southern Alaska. This regional resetting suggests that Alaska was affected by major accretion or plate reorganization in mid-Cretaceous time.

\section{A Speculative Paleogeography of Alaska}

If the paleomagnetic and geological data are taken at face value, a very speculative and interpretative scenario for the tectonic development of Alaska can be assembled. Starting in latest Paleozoic time there probably was an open Aretic Ocean between Eurasia and North America. Arctic Alaska, including much of Chukotka, was adjacent to the continental margin off the Canadian Aretic islands and perhaps also moved nearer to Greenland. The Paleozoic shelf sequences of interior Alaska probably formed part of the continental margin of North America, though their location and orientation with respect to North America are not known.

Far to the south, in equatorial latitudes, there was a large island arc/oceanic plateau destined to become Wrangellia. Parts of what is now the Alexander terrane in southeast Alaska were also south of their present locations, and may have been joined to ancestral Wrangellia. By the beginning of the Mesozoic, the Wrangellia oceanic plateau, the Peninsular and the Alexander terranes were all in fairly close proximity to one another, but still far to the south of their present locations. By Jurassic times, the combined major terranes of southern Alaska, the Southern Alaska Superterrane (Wrangellia, Peninsula and Alexander), together with the fragments of Wrangellia later to be dispersed between Washington state and southeast Alaska, were probably located adjacent to, or close to the North American plate. At this time the Alaska Peninsula portion of the superterrane was part of an active convergent plate boundary and also moving northwards (Panuska and Stone, in Howell, 1985).

The northward movement of the terranes along the edge of North America fragmented and dispersed parts of Wrangellia, presumably by differential motion along the transform boundary. The timing of the arrival of the Southern Alaska Superterrane in Alaska is poorly constrained, and different geological and geophysical arguments give different scenarios. Part of the problem may be due to the unknown complexities of the accretion geometry and the unknown amount of compressional shortening between Arctic Alaska and the southern margin.

In Late Jurassic or Early Cretaceous time, Aretic Alaska began to rift away from Arctic Canada, forming the Canada Basin (Fig. 2). Most of the opening of this basin is presumed to have taken place in Early Cretaceous time, during the Cretaceous normal polarity interval, thus explaining the lack of ocean floor magnetic stripes here. By the Late Cretaceous, the northern ocean between Eurasia and North America was separated from the Pacific by the Arctic Alaska landmass. This landmass also formed a barrier to northward-moving terranes in the Pacific Ocean basin and along its eastern margin with North America, including the Southern Alaska Superterrane. The collision of these northward-moving terranes with the Aretic Alaska barrier may have initiated northward motion for Arctic Alaska and could have been responsible for much of the Brooks Range thrusting.

Island ares, of which there are remnants in western and southwestern Alaska, were also being incorporated into the Alaska collage during Cretaceous time. The accretion of the Southern Alaska Superterrane was followed by that of the Chugach and Prince William (Fig. 1) terranes to the south. The most recent terrane to arrive is the Yakutat block, described earlier, which has apparently moved along the transform margin of North America in the same way envisioned for the earlier arrived terranes (von Huene et al., in Howell, 1985).
A similar process is currently seen in the northward motion of Baja California and is supported by the general northward migration of the terranes of western North America as seen in paleomagnetic data (Stone and MeWilliams, in press, and see Crowell, this issue). The northward migration is presumed to take place by movement along a series of transform faults within a wide zone of transform motion along the plate margin. Differential motion along a wide zone of strike-slip faulting would allow different terranes to move at different rates at different times. This mechanism could allow younger terranes to lie inboard of older terranes as seen in southeast Alaska and western Canada and allow for the dispersion of Wrangellia.

It seems clear that much of Alaska is made up of allochthonous terranes, and that these have amalgamated with one another to form the collage we see today. However, this very broad picture leaves many fundamental questions about the terranes and their amalgamation unanswered. Questions such as the nature and fate of the basement of the terranes, and whether or not terranes are also stacked vertically as a result of major thrusting, need to be answered through continued geological and geophysical investigations.

Dr. D.B. Stone is Professor of Geophysies at the Geophysical Institute, University of Alaska (Fairbanks, Alaska, 99775). He joined the University of Alaska from the University of Newcastle-uponTyne, England to set up a paleomagnetic laboratory. The resulting data have been used to study the geomagnetic field back through time, and to track the movements of the Alaskan terranes.

Dr. W.K. Wallace is on the faculty of the Department of Geology and the Geophysical Institute at the University of Alaska. He has studied the Border Ranges fault, a major terrane boundary in southern Alaska, and the tectonic evolution of many parts of Alaska. His work now centers on the structural geometry and evolution of the Brooks Range fold and thrust belt.
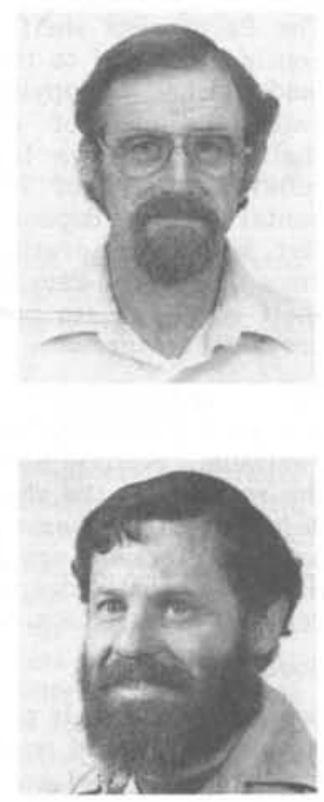

\section{UNESCO COUPONS}

In many countries the shortage of foreign currency hinders the importation of books, publications and scientific material. In some of these countries, Unesco Coupons, whose value is expressed in US dollars, are sold for national currency to educators, research workers and students who use them to pay for their foreign purchases.

In every such country there is a body responsible for the sale of the Coupons; as a rule, this is the National Commission for Unesco. Users pay for the Coupons in national currency at the official United Nations rate of exchange on the day of purchase.

IUGS will accept Unesco Coupons as payment for subscriptions to Episodes and for purchase of other IUGS publications. 
References

Churkin, M., Jr., Foster, H.L., Chapman, R.M. and Weber, F.R., 1982. Terranes and suture zones in east central Alaske. Journal of Geophysical Researeh, v. 87 , no. 5 , p. $3718-3730$.

Cook, D.B., Fujita, K. and MeMullen, C.A., 1986. Presentday plate interactions in northeast Asia: North American, Eurasian, and Okhotsk plates. Journal of Geodynamics, v. $6, \mathrm{p}, 33-52$.

Engebretson, D.C., Cox, A. and Gordon, R.C., 1985. Relative motions between oceanic and continental plates in the Pacific basin. Geological Society America Special Paper 206, p. 59.

Estabrook, C.E., Davies, J.N. and Stone, D.B., in press. Seismotectonics of northern Alaska. Journal of Geophysical Research.

Halgedahl, S.L. and Jarrard, R.D., in press. Paleomagnetism of the Kuparuk River Formation from oriented drill core: evidence for the rotation of the North Slope Block. In: Weimer, P. and Tailleur, 1. (eds.), Alaska North Slope Geology. SEPM-Alaska Geological Society publication.

Harris, R.A., Stone, D.B. and Turner, D.L., 1987. Tectonic implications of paleomagnetic and geochronologic data from the Yukon-Koyukuk provinee. Geological Society of America Bulletin, v. 99, no. 3, p. $362-375$.

Hillhouse, J.W., 1977. Paleomagnetism of the Triassic Nikolai Greenstone, McCarthy Quadrangel, Alaska. Canadian Journal of Earth Seiences, v. 14, no. 11 p. 2578- 2592 .

Howell, D.G. (ed.), 1985. Tectonostratigraphic terranes of the Circum-Pacific region. Circum-Pacific Council for Energy and Mineral Resources, Earth Sciences Series no. 1, p. 3-30.

Jones, D.L., Irwin, W.P. and Ovenshine, A.T., 1972. Southeastern Alaska - a displaced continental fragment? U.S. Geological Survey Professional Paper $800-\mathrm{B}$, p. B211-B 217 .
Jones, D.L., Silberling, N.J., Coney, P.J. and Plafker, G., 1987. Lithotectonic terrane map of Alaska (west of the l4ist meridian). U.S. Geological Survey Nap $\mathrm{MF}-1874-\mathrm{A}$.

Jones, D.L., Silberling, N.J., Csejtey, B., Jr., Nelson, W.H. and Blome, C.D., 1980. Age and structural significance of ophiolite and adjoining rocks in the Upper Chulitna district, south-central Alaska. U.S. Geological Survey Professional Paper 1121-a, $21 \mathrm{p}$.

Jones, D.L., Silberling, N.J., Gilbert, W. and Coney, P., 1982. Character, distribution, and tectonic significance of accretionary terranes in the central Alaska Range. Journal of Geophysical Research, v. 87 , no. 5 , p. 3709-3717.

Jones, D.L., Silberling, N.J. and Hillhouse, J.W., 1977. Wrangellia - a displaced terrane in northwestern North America. Canadian Journal of Earth Seiences, v. 14 no. 11 , p. $2565-2577$.

Lahr, J.C. and Plafker, G., 1980. Holocene PacificNorth American plate interaction in southern Alaska: Implications for the Yakataga seismic gap. Geology v. 8 , no. 10 , p. $483-486$.

Mayfield, C.F., Tailleur, I.L. and Ellersiek, I., 1983. Stratigraphy, structure and palinspastic synthesis of the western Brooks Range, Northwestern Alaska. U.S. Geological Survey open-file report 83-0779, 6lp.

Minster, J.B., Jordan, T.H., Molnar, P. and Haines, E., 1974. Numerical modelling of instantaneous plate tectonics. Geophysical Journal of the Royal Astronomical Society, v. 36, no. 3, p. 541-576.

Monger, J.W.H. and Berg, H.C., 1987. Lithotectonic terrane map of western Canada and southeastern Alaska, U.S. Geological Survey Map MF-1874-B.

Monger, J.W.H. and Ross, C.A., 1971. Distribution of Fusulinaceans in the western Canadian Cordillera. Canadian Journal of Earth Sciences, v. 8, no. 2, p. 259-278.
Mull, C.G., 1982. Tectonic evolution and structural style of the Brooks Range, Alaska: an illustrated summary. In: Powers, K.B. (ed.), Geologic studies of the Cordilleran thrust belt. Rocky Mountain Association of Geologists, Denver, Colo., p. 1-45.

Oldow, J.S, Ave Lallanent, U.G., Julian, F.E, and Seidensticker, C.M., 1987. Lllsmerian(?) and Brookian deformation in the Franklin Mountains, northeastern Brooks Range, Alaska, and its bearing on the origin of the Canada Basin. Ceology, v. 15, no. 1, p. 37-41.

Packer, D.R. and Stone, D.B., 1972. An Alaskan Jurassic paleomagnetic pole and the Alaskan oroctine. Nature, $v .237$, p. 25-20.

Panuska, B.C., 1985. Faleomagnetic evidence for a post Cretaceous accretion of Wrangellia. Geology, v. 13 , no. 12, p. 880-883.

Patton, W.W., Jr. and Tailleur, L.L., 1977 . Evidence in the Bering Strait region for differential movement between North America and Eurasia. Geological Society of America Bulletin, v. 88, no. 9, p. 12981304.

Stephens, C.D., Fogleman, K.A., Lahr, J.C. and Page, R.A., 1984. Wrangell Benioff Zone, southern Alaska. Geology, v. 12, no. 6, p. 373-376.

Stone, D.B. and howilliams, M., in press. paleomagnetic evidence for relative lerrane motion in western North America. In Ben Avraham, $Z$ (ed), Evolution of the Pacific margins. Oxford University Press.

Stone, 0.B. 1983. Present day plate boundaries in Alaska and the Arctic. In: Western Alaska Geology and
Resource Potential. Journal of the Alaska Geological Resource Potential. Jour
Society, v. 3, p. 1-14.

Wallace, W.K. and Engebretson, D.C., 1984. Relationships between plate motions and Late Cretaceou to Paleogene magmatism in southwestern Alaska. Tectonics, v. 3 , no. 2 , p. $293^{-} 315$, publishers cor rection p. $497-498$
Izu Oshima! Rabaul! Mt. Etna! Kilauea! Volcanoes exist in many places, but in North America, the place to witness the beauty of an active volcano is - HAWAII
If you are planning a field trip or vacation to Hawaii, or are planning to visit Hawaii during the International Geological Congress or the IAVCEI Volcanological Congress in 1989,

then, this is the bookfor you!

\title{
Highway Geology of the Hawaiian Islands - Hawaii, Maui, Oahu, Kauai and Molokai
}

\author{
by R. Michael Easton and Monica Gaiswinkler Easton \\ 1987, 168 pages + 87 figures, spiral bound (rust-proof) \\ ISBN 0-9692824-0-0
}

The only field guidebook of Hawaiian geology of ALL the islands in ONE book, and the only book in roadlog format. Suitable for individual, group or student trip use, and fills a gap between guides for the layman and hard-to-get technical trip guides.

Each of the five chapters begins with a summary of the island's geology, and continues with a roadlog format for the important hiking trails, biways and main highways, all arranged for convenient full or half-day field trips. References are grouped at the end of the book for ease of use.
Order your copy today, from:

Easton Enterprises, Department E

19 Gable Drive, Brampton, Ontario, Canada L6V 2H2

Price:

For Canadian orders: $\$ 20 \mathrm{CDN}$ (+ postage and handling per book: surface: $\$ 2 \mathrm{CDN}$; air: $\$ 5 \mathrm{CDN}$ ) For International orders: \$15 US (+ postage and handling per book: surface: \$3 US; air: \$8 US)

Cheques or money orders must be in $\$$ Canadian for orders in Canada, \$ United States for foreign orders. 


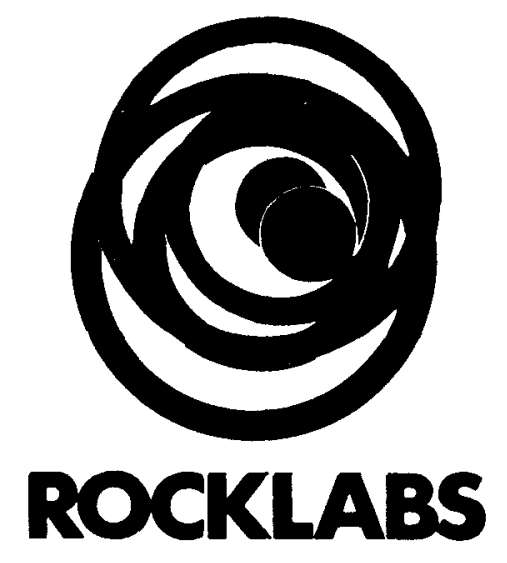

$\begin{array}{ll}\text { Manufacturers of: } & \text { RING MILLS } \\ & \text { HYDRAULIC CRUSHERS } \\ & \text { PERCUSSION MORTARS } \\ \text { SWING JAW CRUSHERS } \\ \text { CONTINUOUS FEED MILLS } \\ \text { MULTI-MILLS (80 samples at once) }\end{array}$

\title{
Have you seen our ZIRCONIA Ring Mill Head?
} The only one in the world.

Ideal for trace and ultra-trace analysis. Can be used on your brand of Ring Mill or ours. Costs less than agate or tungsten carbide. Please ask for a brochure.

We hope to see you at our display at IGC, Washington, D.C., U.S.A. 1989.

For information, brochures, prices, agent's address etc. please contact:

\author{
Dr. Ian Devereux, Manager \\ ROCKLABS \\ P.O. box 18-142 \\ Auckland, New Zealand \\ TLX NZ60550, Phone (9) 574-698
}

\section{ROCKLABS - P r o v e $\mathrm{p}$ e r f o r m e r s}

We have agents in Australia, Canada, Chile, Indonesia, Japan, Korea, Peru, Philippines, U.K. and U.S.A. 